\title{
SEM plays an important role in the study of fossil clam shrimps
}

\author{
Gang Li Ph.D
}

Li G. SEM plays an important role in the study of fossil clam shrimps. J Environ Geol 2017;1(1)-22-23.

\begin{abstract}
Clam shrimps are large branchiopod crustaceans with laterally compressed bodies enclosed by a bivalved chitinous (1) or complex chitin-mineral carapace (2). They can be found on all continents except Antarctica. They generally inhabit seasonally astatic wetlands such as playas, vernal pools, rice field, inundated road ruts or fishless lakes (3). Because their resting eggs are able to survive dormant for several years under dry conditions, they are able to rapidly colonize seasonal water pools after flooding (4). Thus they are important components of the ephemeral water ecosystems, and indicate the alternation of a wet/dry seasonal climate.
\end{abstract}

Fossil clam shrimps are more widely distributed [even on Antarctica] (5) in the deep time of earth history. They have a geological history that extends back to the Devonian. Initially, their evolution was centred on Europe but during the Mesozoic they diversified more rapidly in Asia. During the Cenozoic they gradually declined in both numbers and variety (6). Fossil clam shrimps are commonly abundant and widely distributed in sediments that accumulated in quiet, freshwater environments. As a result, they can be useful index fossils for biostratigraphic subdivision and correlation of non-marine successions. However, other taxa may occur in deposits of the same age in different drainage basins, reflecting local geographic and climatic variations and/or differences in the physical and chemical conditions within the water (3).

Fossil clam shrimps are commonly preserved as calcium phosphate carapace (5) or their external or internal moulds. The fossilized soft parts of clam shrimps are very rare (7). This means that the taxonomy of fossil clam shrimps is mainly based on the structure and features of the fossilized carapace, which nowadays have been accommodated in four suborders (3): i.e. Laevicaudata, Spinicaudata, Estheriellina and Leaiina. F Scholze and JW Schneide (8) introduced improved methodology for the description of fossil clam shrimps. Although the taxonomic features, such as the carapace size and outline, the umbo size and its position, are easy observed by the help of light microscope, the more delicate ornamentation on the carapace cannot be clearly observed under a light microscope.

Nowadays scanning electron microscopes [SEMs] are widely available and play a more important role in the taxonomy of fossil clam shrimps. The previous studies of fossil clam shrimps were mainly based on the observation under a light microscope. This makes the description of carapace ornamentation features unprecise, and thus taxonomic relationships cannot be determined clearly. OF Gallego et al. (9) re-illustrated the geographically and stratigraphically widely distributed Early Cretaceous species Martinsestheria codoensis using an SEM, and found two pattern ornamentation on growth bands: i.e. the polygonal reticulation in the dorsal part and scarce shallow ovate cavities filled with minute puncta in the ventral part of the carapace. Thus, the species was moved out of the genus Lioestheria and was designated as a type species of the new genus Martinsestheria. The genus Migransia was reported from the Upper Jurassic Penglaizhen Formation of Sichuan Province, southwestern China. A new SEM imaging of the type material of Migransia sichuanensis has revealed the similar carapace ornamentation as in Qinhaiestheria from the Kimmeridgian Hongshuigou Formation of Qinghai Province, northwestern China. They both have radial lirae, cross bars and puncta. Thus, Migransia sichuanensis should be assigned to Qinghaiestheria (10). This research result supports the correlation of the Penglaizhen Formation of Sichuan with the Hongshuigou Formation of Qinghai.

More SEM studies suggested that serrated growth lines are only of taxonomic significance for the generic or subgeneric level, not for the family rank. Although many previous studies suggested that the serration along the lower margins of growth lines was a diagnostic feature for the family Afrograptidae, this feature has been recovered in many fossil clam shrimp taxa: such as Cratostracus (11), Ordosestheria (12), Porostracus (11) of the family Fushunograptidae, Estherites (13), Euestherites (13) of the family Estheriteidae, Dictyestheria (14), Halysestheria (14), Plectestheria (14), Tylestheria (15) of the family Halysestheriidae. The list would be much longer if further SEM studies would be undertaken. Thus, YB Shen (16) has moved many taxa out of the family Afrogratidae and reassigned them to different families.

Recent SEM studies of fossil clam shrimps have discovered more delicate ornamentation on growth bands. G Li et al. (1) have found small punta on growth bands, which have not been discernable under a light microscope. YL Li et al. (17) re-examined Diestheria longinqua from the Lower Cretaceous Yixian Formation of western Liaoning Province, northeastern China. More delicate morphological features on the carapace have been revealed: 1) growth lines with fine ridges; 2) radial lirae intercalated with small irregular reticulation on the growth bands in the postero-middle part of the carapace. $\mathrm{G} \mathrm{Li}$ et al. (18) re-examined the specimen of Ganestheria longnanensis from the Upper Cretaceous of southeastern China under an SEM, and revealed morphological features on the carapace that had not been recognized previously: widely spaced radial lirae on growth bands intercalate large-sized polygonal reticulation, within which small-sized reticulation also occurs.

The use of an SEM is essential in the study of fossil clam shrimps, so that the species and genera can be adequately compared with each other and also their biostratigraphic value can be increased (19-21). There are a lot of similar issues and problems in this area that are waiting for being resolved. So that the distribution pattern and biogeography of fossil clam shrimps can further be discussed (3). The journal "Environmental Geology" can be a great place to share the achievements of modern researchers in this field.

This study was supported by National Natural Science Foundation of China [41572006, 41688103, 91514302, 41172010] and the Chinese Academy of Sciences [XDPB05].

\section{REFERENCES}

1. Li G, Ohta T, Batten DJ, et al. Morphology and phylogenetic origin of the spinicaudatan Neodiestheria from the Lower Cretaceous Dalazi Formation, Yanji Basin, north-eastern China. Cretaceous Research 2016;62:183-93.

2. Astrop TI, Hegna TA. Phylogenetic relationships between living and fossil spinicaudatan taxa (Branchiopoda Spinicaudata): reconsidering the evidence. Journal of Crustacean Biology 2015;35:339-54.

3. Li G. Revision of fossil clam shrimp taxonomy and a case study on palaobiogeography of jurassic clam shrimps in China. Journal of Environment and Bio Research 2017;1(1):1-6.

4. Guériau P, Clément G, Lagebro L, et al. A 365-million-year-old freshwater community reveals morphological and ecological stasis in branchiopod crustaceans. Current Biology 2016;26:383-90.

5. Stigall AL, Babcock LE, Briggs DEG, et al. Taphonomy of Lacustrine Interbeds in the Kirkpatrick Basalt (Jurassic), Antarctica. Palaios 2008;23:344-55.

6. Chen PJ, Li G, Batten DJ. Evolution, migration and radiation of late Mesozoic conchostracans in East Asia. Geological Journal 2007;42(3-4):391413.

State Key Laboratory of Palaeobiology and Stratigraphy, Nanjing Institute of Geology and Palaeontology, Chinese Academy of Sciences, China

Correspondence: Gang Li, State Key Laboratory of Palaeobiology and Stratigraphy, Nanjing Institute of Geology and Palaeontology, Chinese Academy of Sciences, East Beijing Road 39, Nanjing 210008, PR China. Telephone: +86-25-83282190, e-mail: gangli@nigpas.ac.cn

Received: October 17, 2017, Accepted: October 20, 2017, Published: October 24, 2017

\footnotetext{
OPEN ACCESS

This open-access article is distributed under the terms of the Creative Commons Attribution Non-Commercial License (CC BY-NC) (http:// creativecommons.org/licenses/by-nc/4.0/), which permits reuse, distribution and reproduction of the article, provided that the original work is properly cited and the reuse is restricted to noncommercial purposes. For commercial reuse, contact reprints@pulsus.com
} 
7. Orr PJ, Briggs DEG. Exceptionally preserved conchostracans and other crustaceans from the upper carboniferous of Ireland. Special Papers in Palaeontology, Palaeontological Association, London. 1999;62:5-68.

8. Scholze F, Schneider JW. Improved methodology of 'conchostracan' (Crustacea: Branchiopoda) classification for biostratigraphy. Newsletters on Stratigraphy 2015;48(3):287-98.

9. Gallego OF, Monferran MD, Astrop TI, et al. Reassignment of Lioestheria codoensis Cardoso (Spinicaudata, Anthronestheriidae) from the Lower Cretaceous of Brazil: systematics and paleoecology. Revista Brasileira de Paleontologia 2013;16:47-60

10. Li G. Discovery of Qinghaiestheria from the Upper Jurassic Penglaizhen Formation in Sichuan, southwestern China. Journal of Asian Earth Sciences 2004;24(3):361-365.

11. Li G, Batten DJ. Revision of the conchostracan genera Cratostracus and Porostracus from Cretaceous deposits in north-east China. Cretaceous Research 2004;25(6): 919-26.

12. Li G. SEM morphological study of the type species of Ordosestheria Wang, 1984 (Spinicaudata) from Ordos Basin of mid-west China. Cretaceous Research 2017;75:1-6.

13. Li G, Batten DJ. Revision of the conchostracan genus Estherites from the Upper Cretaceous Nenjiang Formation of the Songliao Basin and its biogeographic significance in China. Cretaceous Research 2005;26(6):920-929.

14. Li G, Wan XQ, Batten DJ, et al. Spinicaudatans from the Upper
Cretaceous Nenjiang Formation of the Songliao Basin, northeast China: taxonomy and biostratigraphy. Cretaceous Research 2009;30(3):687-698.

15. Li G, Matsuoka A. Revision of clam shrimp (“conchostracan”) genus Tylestheria from Late Cretaceous deposits of China. Science Reports of Niigata University (Geology) 2013;28:51-63.

16. Shen YB. Review of the classification of the Family Afrograptidae (Crustacea: Conchostraca). Acta Palaeontologica Sinica 2003;42:590-97.

17. Li YL, Teng X, Matsuoka A, et al. SEM morphological study of clam shrimp Diestheria (spinicaudatan) of the Jehol Biota of China. Science Reports of Niigata University (Geology) 2017;32:15-23.

18. Li G, Teng X, Matsuoka A. SEM morphological study of clam shrimp Ganestheria (spinicaudatan) from Upper Cretaceous of Jiangxi, southeastern China. Science Reports of Niigata University (Geology) 2016;31:69-74.

19. Teng X, Li G. Clam shrimp genus Ordosestheria from the Lower Cretaceous Dalazi Formation in Jilin Province, north-eastern China. Cretaceous Research 2017;78:196-205.

20. Li G. Morphological restudy of the type species of Xibeiestheria (Spinicaudata) from the lower Aptian, northwestern China. Cretaceous Research 2017;80:31-7.

21. Boukhalfa K, Li G, Ben Ali W, et al. Early Cretaceous spinicaudatans ("conchostracans") from lacustrine strata of the Sidi Aïch Formation in the northern Chotts range, southern Tunisia: Taxonomy, biostratigraphy and stratigraphic implication. Cretaceous Research 2015;56:482-90. 